Artikel Penelitian

\title{
Hubungan Pengetahuan dan Sikap dengan Perilaku Pencegahan Filariasis di Kecamatan Cilimus Kabupaten Kuningan
}

\author{
Correlation of Knowledge and Attitude with Filariasis Prevention Practices in Cilimus \\ Subdistrict Kuningan Regency
}

Nissa Noor Annashr ${ }^{1 *}$, Fathi Muhamad Rahmadi ${ }^{1}$

${ }^{1}$ Program Studi Kesehatan Masyarakat, Fakultas Ilmu Kesehatan, Universitas Siliwangi, Tasikmalaya, 46115, Indonesia

Kutipan: Annashr NN, Rahmadi FM. Hubungan Pengetahuan dan Sikap dengan Perilaku Pencegahan Filariasi di Kecamatan Cilimus Kabupaten Kuningan. ASP. Juni 2021:13(1): 23-36

Editor: Sunaryo Diterima: 04 Maret 2021 Revisi: 11 Mei 2021 Layak Terbit: 4 Juni 2021

Catatan Penerbit: Aspirator tetap netral dalam hal klaim yurisdiksi di peta yang diterbitkan dan afiliasi kelembagaan.

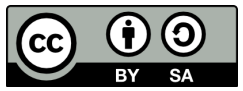

Hak Cipta: (C) 2021 oleh penulis. Pemegang lisensi Loka Litbangkes Pangandaran, Indonesia. Artikel ini adalah artikel dengan akses terbuka yang didistribusikan dengan syarat dan ketentuan lisensi Creative Commons Attribution Share-Alike (CC BY SA) (https:// creativecommons.org/licenses/by$\mathrm{sa} / 4.0 /)$

*Korespondensi Penulis.

Email: annashr.nissa46@gmail.com
Abstract. Lymphatic filariasis is a chronic infectious disease caused by parasitic nematodes. The worm can damage the human lymphatic system gradually then causing enlargement of the limbs, breasts and genitalia. Kuningan is an endemic regency for filariasis in West Java Province. Cilimus District was in the 2 nd position as a district with the highest filariasis cases in Kuningan in 2017. This research was conducted in Cilimus District from May to June 2018 using a cross-sectional design. The population was all households in the Cilimus District with a sample size of 106 people who were taken using a simple random sampling technique. The independent variables studied were knowledge and attitudes regarding the prevention of filariasis, the dependent variable was the filariasis prevention practices. Data collection was carried out by interview using a questionnaire. Data analysis was performed by univariate and bivariate (chi-square test). The results showed that some respondents had good knowledge and positive attitudes about the prevention of filariasis (50\%). The description of respondent practices showed that $82.1 \%$ of respondents took filariasis drug, $62.3 \%$ of respondents had the habit of using mosquito repellent, only $4.7 \%$ of respondents used mosquito nets, $49.1 \%$ of respondents put gauze wire, $47.2 \%$ of respondents did not have a habit of hanging clothes. The results of categorizing behavioral variables were found that more than half of the respondents $(52.8 \%)$ had implemented good prevention practices. The results of the bivariate analysis showed that there was a significant relationship between knowledge and attitude with filariasis prevention practices $(p<0.05)$.

Keywords: Knowledge, attitude, practice, prevention, Filariasis

Abstrak. Filariasis limfatik termasuk ke dalam penyakit infeksi kronis yang disebabkan oleh cacing nematoda parasit. Cacing tersebut dapat merusak sistem limfatik manusia secara bertahap sehingga menyebabkan pembesaran anggota badan, payudara dan genitalia. Kuningan merupakan kabupaten endemis filariasis di Jawa Barat. Kecamatan Cilimus berada pada posisi ke-2 sebagai kecamatan dengan kasus filariasis tertinggi di Kabupaten Kuningan pada 2017. Penelitian ini dilakukan di Kecamatan Cilimus pada bulan Mei hingga Juni 2018 menggunakan rancangan potong lintang. Populasi dalam penelitian ini adalah seluruh kepala keluarga di Kecamatan Cilimus dengan besar sampel sebanyak 106 orang yang diambil menggunakan teknik simple random sampling. Variabel independen yang diteliti berupa pengetahuan dan sikap mengenai pencegahan filariasis, sedangkan variabel dependen berupa perilaku pencegahan filariasis. Pengumpulan data dilakukan dengan wawancara menggunakan kuesioner. Analisis data dilakukan secara univariat dan bivariat (uji chi square). Hasil penelitian menunjukkan sebagian responden memiliki pengetahuan yang baik dan sikap positif mengenai pencegahan filarisis (50\%). Gambaran perilaku responden menunjukkan $82,1 \%$ responden minum obat pencegahan filariasis, $62,3 \%$ responden memiliki kebiasaan menggunakan obat nyamuk, hanya 4,7\% responden yang menggunakan kelambu, 49,1\% responden memasang kawat kasa, 47,2\% responden tidak memiliki kebiasaan menggantung pakaian. Hasil kategorisasi variabel perilaku didapatkan lebih dari sebagian responden $(52,8 \%)$ sudah menerapkan perilaku pencegahan filariasis yang baik. Hasil analisis bivariat menunjukkan terdapat hubungan yang signifikan antara variabel pengetahuan dan sikap dengan perilaku pencegahan filariasis $(p<0,05)$.

Kata Kunci: Pengetahuan, sikap, perilaku, pencegahan, filariasis 


\section{PENDAHULUAN}

Filariasis limfatik (FL) merupakan penyakit menular yang telah menjadi masalah kesehatan masyarakat di Indonesia sejak lama. ${ }^{1}$ Hingga saat ini, filariasis masih berjangkit di sebagian besar wilayah Indonesia dan dapat menyebabkan kecacatan seumur hidup. ${ }^{2}$ Sejak tahun 1997, WHO bahkan telah menetapkan penyakit ini sebagai neglected tropical disease (NTD) yang menjadi masalah kesehatan masyarakat di dunia. ${ }^{1}$ Filariasis limfatik merupakan penyakit endemis di 72 negara di daerah tropis dan subtropis serta menyebabkan sekitar 1,4 miliar penduduk di daerah endemis berisiko tertular oleh penyakit ini. ${ }^{3}$

Filariasis limfatik termasuk ke dalam penyakit infeksi kronis yang disebabkan oleh tiga spesies nematoda parasit mirip benang, yaitu Wuchereria bancrofti, Brugia malayi, dan Brugia timori. ${ }^{3,4}$ Cacing tersebut dapat merusak sistem limfatik manusia dan menghalangi aliran getah bening secara bertahap sehingga menyebabkan pembesaran anggota badan, payudara, dan genitalia. ${ }^{4}$ Sebagian besar penduduk yang terinfeksi cacing filariasis mengalami morbiditas yang signifikan, terutama limfedema kronis pada kaki, lengan, payudara, elefantiasis atau kaki gajah dan hidrokel. Selain itu, berdampak juga terhadap timbulnya kecacatan sehingga menghambat perkembangan sosial ekonomi dan meningkatkan kemiskinan di banyak negara endemis., ${ }^{5,6} \mathrm{Hal}$ ini terbukti dari pengamatan bahwa $94 \%$ negara dengan indeks pembangunan manusia (IPM) terendah adalah endemis FL. ${ }^{6}$

Data Riset Kesehatan Dasar (RISKESDAS) tahun 2018 menunjukkan prevalensi kasus filariasis di Indonesia sebesar 0,8\%, dengan provinsi yang memiliki prevalensi terbesar adalah Provinsi Maluku, yaitu sebesar 1,8\% dan provinsi dengan prevalensi terkecil adalah Provinsi Bali, yaitu sebesar 0,4\%.7 Sementara itu, Provinsi Jawa Barat merupakan salah salah satu provinsi yang memiliki prevalensi filariasis yang lebih tinggi dibandingkan prevalensi nasional, yaitu sebesar $0,98 \%{ }^{8}$

Beberapa penelitian sebelumnya telah mengkonfirmasi banyak faktor yang dapat memengaruhi terjadinya filariasis di Indonesia. Secara garis besar meliputi faktor sosiodemografi, kondisi lingkungan dan PSP (pengetahuan, sikap, dan perilaku). Hasil penelitian sebelumnya menunjukkan faktor-faktor yang terbukti memiliki hubungan yang signifikan dengan kejadian filariasis yaitu pengetahuan mengenai filariasis, ${ }^{9,10,11,12}$ sikap, ${ }^{13}$ jenis pekerjaan, ${ }^{12}$ umur, ${ }^{14}$ dan jenis kelamin. ${ }^{12}$

Faktor perilaku yang telah terbuktimemiliki pengaruh positifterhadap pengendalian filariasis melalui penelitian sebelumnya, yaitu praktik minum obat pencegahan filariasis setiap bulan Oktober, ${ }^{12,15}$ kebiasaan menggunakan kawat kasa pada ventilasi; ${ }^{16,17,18}$ kebiasaan menggunakan obat nyamuk oles; kebiasaan menggunakan baju panjang dan celana panjang saat keluar rumah malam hari, ${ }^{12}$ serta kebiasaan menggunakan kelambu saat tidur. ${ }^{18}$ Faktor perilaku negatif yang dapat meningkatkan risiko penularan filariasis adalah kebiasaan ke luar rumah malam hari ${ }^{12}$ dan pengendalian vektor belum dilakukan dengan baik. ${ }^{11}$ Adapun faktor lingkungan terdiri dari kepadatan hunian, ${ }^{15}$ keberadaan tempat perindukan nyamuk, kondisi sanitasi sekitar rumah, ${ }^{12}$ keberadaan kandang ternak di sekitar rumah, ${ }^{12,18}$ keberadaan rawa-rawa, keberadaan perkebunan/hutan, ${ }^{18}$ keberadaan tempat peristirahatan, dan berkembangbiaknya vektor. ${ }^{13}$

Diketahuinya faktor-faktor yang dapat memengaruhi terjadinya filariasis di suatu wilayah dibutuhkan upaya dari masyarakat untuk dapat menerapkan perilaku pencegahan filariasis dan memodifikasi lingkungan supaya tidak menjadi tempat perkembangbiakan vektor. Filariasis limfatik sebagai penyakit tropis terabaikan, berpotensi untuk dikendalikan dan dihilangkan dari masyarakat. Pengendalian dapat dimungkinkan melalui kemoterapi preventif, pengendalian vektor, penguatan sistem kesehatan, peningkatan higiene dan manajemen kasus penyakit yang tepat. ${ }^{19}$

Kabupaten Kuningan, Provinsi Jawa Barat memiliki prevalensi kasus filariasis sebesar $0,74 \% .{ }^{8}$ Kabupaten Kuningan wilayahnya terdiri dari 32 kecamatan, salah 
satunya Kecamatan Cilimus. Kecamatan Cilimus menjadi daerah endemis filariasis karena terdapat dua kasus kronis filariasis pada tahun 2017. Hal tersebut menjadikan Cilimus berada pada posisi ke-2 sebagai kecamatan dengan kasus filariasis tertinggi di Kabupaten Kuningan. Tujuan penelitian ini adalah mengetahui gambaran pengetahuan, sikap dan perilaku pencegahan filariasis, serta menganalisis hubungan antara pengetahuan dan sikap dengan perilaku pencegahan filariasis di Kecamatan Cilimus, Kabupaten Kuningan.

\section{BAHAN DAN METODE}

Penelitian ini dilakukan di Kecamatan Cilimus, Kabupaten Kuningan pada bulan Mei hingga Juni 2018. Penelitian ini merupakan penelitian observasional analitik dengan rancangan studi potong lintang. Populasi dalam penelitian ini adalah seluruh kepala keluarga di Kecamatan Cilimus, Kabupaten Kuningan. Besar sampel dalam penelitian ini sebanyak 106 orang yang diperoleh dari perhitungan rumus Lemeshow. Pengambilan sampel penelitian menggunakan teknik simple random sampling. Kriteria sampel dalam penelitian ini adalah: 1) tidak menderita filariasis; 2) tidak menderita penyakit berat; 3) tidak hamil pada saat program pemberian obat pencegahan masal (POPM) berlangsung; 4) bersedia menjadi sampel penelitian.

Variabel independen yang diteliti berupa tingkat pengetahuan dan sikap mengenai pencegahan filariasis, sedangkan variabel dependen berupa perilaku pencegahan filariasis. Perilaku tersebut meliputi minum obat pencegahan filariasis, kebiasaan menggunakan obat nyamuk, kebiasaan menggunakan kelambu, perilaku menggunakan kawat kasa pada ventilasi rumah, kebiasaan menggantung pakaian, kebiasaan menutup tempat penampungan air, kebiasaan menguras bak mandi, dan kebiasaan mengelola barang bekas.

Pengumpulan data dilakukan dengan wawancara kepada sampel penelitian, menggunakan kuesioner. Dalam kuesioner tersebut, terdapat 15 butir pertanyaan untuk mengukur variabel pengetahuan, 10 butir pernyataan untuk mengukur variabel sikap, dan 5 pertanyaan untuk mengukur variabel perilaku pencegahan filariasis.

Bagi pertanyaan mengenai pengetahuan, setiap jawaban benar diberi nilai 1 dan jawaban salah diberi nilai 0 . Dari 15 pertanyaan tersebut, dihitung berapa total nilai setiap responden. Variabel pengetahuan diklasifikasikan menjadi tiga kategori yaitu baik, jika jawaban benar responden berkisar 76\%-100\%, cukup jika jawaban benar responden berkisar 56\%-75\%, dan kurang jika jawaban benar responden $<56 \%$. Untuk memudahkan dalam melakukan analisis bivariat, variabel pengetahuan dikategorikan menjadi dua kategori yaitu cukup-baik dan kurang. Kategori cukup-baik merupakan gabungan dari kategori cukup dan baik sehingga yang termasuk ke dalam kategori ini adalah responden yang memiliki jawaban benar berkisar 56\%-100\%.

Pada pernyataan mengenai sikap, tersedia dua opsi yang harus dipilih responden pada setiap pernyataan yaitu "setuju" dan "tidak setuju". Jika pernyataan positif dan responden memilih opsi "setuju", maka responden diberi nilai 1, sebaliknya jika opsi yang dipilih "tidak setuju", diberi nilai 0 . Namun, jika pernyataan negatif dan responden memilih opsi "tidak setuju" maka responden diberi nilai 1, sebaliknya jika opsi yang dipilih "setuju", diberi nilai 0 . Kemudian, nilai dari 10 pernyataan dijumlahkan. Jika responden memiliki nilai $<$ 7,50 maka responden dikategorikan memiliki sikap negatif. Namun, jika responden memiliki nilai $\geq 7,50$ dikategorikan memiliki sikap positif. Nilai 7,50 merupakan nilai median dari data mengenai variabel sikap. Kategorisasi menggunakan nilai median sebagai nilai batas karena data mengenai variabel sikap tidak berdistribusi normal. 
Kategorisasi variabel perilaku dilakukan dengan cara menjumlahkan nilai dari 5 pertanyaan mengenai variabel perilaku (minum obat pencegahan filariasis, kebiasaan menggunakan obat nyamuk, kebiasaan menggunakan kelambu, perilaku menggunakan kawat kasa pada ventilasi rumah, kebiasaan menggantung pakaian), kemudian nilai tersebut dibandingkan dengan nilai median (3). Jika nilai responden $<3$ maka perilaku mereka tergolong memiliki perilaku kurang baik, sebaliknya jika responden memliki nilai $\geq 3$ maka responden memiliki perilaku yang baik. Penggunaan nilai median sebagai cut of point karena data tidak berdistribusi normal.

Setelah data selesai dikumpulkan, kemudian diolah dan dianalisis secara univariat dan bivariat. Perangkat lunak yang digunakan untuk melakukan analisis data adalah SPSS Statistics (IBM). Analisis bivariat dilakukan untuk: 1) menganalisis hubungan antara variabel pengetahuan dan perilaku pencegahan filariasis, dan 2) menganalisis hubungan antara variabel sikap dan perilaku pencegahan filariasis. Adapun proses analisis bivariat menggunakan uji chi square.

\section{HASIL}

\section{Gambaran Variabel Pengetahuan dan Sikap tentang Pencegahan Filariasis di Kecamatan Cilimus}

Berikut adalah gambaran mengenai jawaban responden terhadap setiap butir pertanyaan untuk mengukur variabel pengetahuan dalam kuesioner.

Tabel 1. Distribusi Frekuensi Butir Pertanyaan Variabel Pengetahuan

\begin{tabular}{|c|c|c|c|c|c|}
\hline \multirow{3}{*}{ No. } & \multirow{3}{*}{ Pertanyaan } & \multicolumn{4}{|c|}{ Jawaban } \\
\hline & & \multicolumn{2}{|c|}{ Salah } & \multicolumn{2}{|c|}{ Benar } \\
\hline & & $\mathrm{F}$ & $\%$ & $\mathrm{~F}$ & $\%$ \\
\hline 1. & Apakah penyakit filariasis (kaki gajah) itu? & 44 & 41,5 & 62 & 58,5 \\
\hline 2. & Apa penyebab penyakit filariasis (kaki gajah)? & 49 & 46,2 & 57 & 53,8 \\
\hline 3. & Apakah penyakit filariasis merupakan penyakit menular? & 36 & 34,0 & 70 & 66,0 \\
\hline 4. & Penyakit filariasis (kaki gajah) ditularkan oleh? & 35 & 33,0 & 71 & 77,0 \\
\hline 5. & Lingkungan yang berisiko untuk penularan filariasis (kaki gajah) adalah? & 27 & 25,5 & 79 & 74,5 \\
\hline 6. & $\begin{array}{l}\text { Kondisi lingkungan di dalam rumah yang meningkatkan risiko penularan } \\
\text { filariasis (kaki gajah) adalah? }\end{array}$ & 15 & 14,2 & 91 & 85,8 \\
\hline 7. & $\begin{array}{l}\text { Kegiatan yang dapat dilakukan untuk mencegah filariasis (kaki gajah) } \\
\text { adalah? }\end{array}$ & 12 & 11,3 & 94 & 88,7 \\
\hline 8. & $\begin{array}{l}\text { Bagaimanakah kegiatan untuk menjaga lingkungan supaya tidak menjadi } \\
\text { tempat perindukan nyamuk? }\end{array}$ & 1 & 0,9 & 105 & 99,1 \\
\hline 9. & $\begin{array}{l}\text { Manakah yang bukan cara pencegahan penyakit filariasis (kaki gajah) } \\
\text { yang dapat dilakukan? }\end{array}$ & 42 & 39,6 & 64 & 60,4 \\
\hline 10. & $\begin{array}{l}\text { Apakah minum obat filariasis (kaki gajah) dapat mencegah dari } \\
\text { penularan kaki gajah? }\end{array}$ & 14 & 13,2 & 92 & 86,7 \\
\hline 11. & Apa kepanjangan dari POMP? & 46 & 43,4 & 60 & 56,6 \\
\hline 12. & Apa manfaat dari minum obat POMP filariasis yang diberikan petugas? & 66 & 62,3 & 40 & 37,7 \\
\hline 13. & Siapa sajakah yang diwajibkan mengikuti pengobatan masal filariasis? & 25 & 23,6 & 81 & 76,4 \\
\hline 14. & Apakah ada efek samping dari minum obat POMP filariasis? & 29 & 27,4 & 77 & 72,6 \\
\hline 15. & $\begin{array}{l}\text { Apa yang dilakukan kalau seseorang sudah terkena penyakit filariasis } \\
\text { (kaki gajah)? }\end{array}$ & 0 & 0,0 & 106 & 100,0 \\
\hline
\end{tabular}

Berdasarkan Tabel 1, diketahui bahwa pertanyaan yang dapat dijawab dengan benar oleh semua responden adalah pertanyaan no. 15 mengenai tindakan apa yang harus dilakukan jika seseorang terserang filariasis. Adapun, pertanyaan yang paling banyak dijawab salah oleh responden adalah pertanyaan no. 12 mengenai mengenai manfaat minum obat dari Program POPM (62,3\%). Gambaran mengenai jawaban responden terhadap setiap butir pertanyaan variabel sikap diperlihatkan pada Tabel 2. 
Tabel 2. Distribusi Frekuensi Butir Pernyataan Variabel Sikap Kategori Perilaku Pencegahan Filariasis

\begin{tabular}{|c|c|c|c|c|c|}
\hline \multirow{3}{*}{ No. } & \multirow{3}{*}{ Pernyataan } & \multicolumn{4}{|c|}{ Jawaban } \\
\hline & & \multicolumn{2}{|c|}{ Setuju } & \multicolumn{2}{|c|}{ Tidak Setuju } \\
\hline & & F & $\%$ & $\mathrm{~F}$ & $\%$ \\
\hline 1 & $\begin{array}{l}\text { Apabila saudara menderita penyakit kaki gajah, maka akan langsung berobat } \\
\text { ke puskesmas atau dokter. }\end{array}$ & 106 & 100,0 & 0 & 0,0 \\
\hline 2 & Penyakit filariasis (kaki gajah) merupakan penyakit yang dapat dicegah. & 100 & 94,3 & 6 & 5,7 \\
\hline 3 & $\begin{array}{l}\text { Pada acara halalbihalal kampung, warga sebaiknya menghindari bersalaman } \\
\text { dengan penderita filariasis (kaki gajah) supaya tidak tertular. }\end{array}$ & 73 & 68,9 & 36 & 31,1 \\
\hline 4 & $\begin{array}{l}\text { Jika salah satu keluarga saudara menderita filariasis (kaki gajah), keluarga } \\
\text { yang tinggal serumah dengannya, sebaiknya selalu memakai obat nyamuk dan } \\
\text { repellent anti-nyamuk agar tidak tertular filariasis (kaki gajah). }\end{array}$ & 86 & 81,1 & 20 & 18,9 \\
\hline 5 & $\begin{array}{l}\text { Apabila salah satu keluarga saudara menderita filariasis (kaki gajah), keluarga } \\
\text { yang tinggal serumah dengannya selalu memisahkan alat makan dan pakaian } \\
\text { yang dipakai penderita agar tidak tertular filariasis (kaki gajah). }\end{array}$ & 54 & 50,9 & 52 & 49,1 \\
\hline 6 & $\begin{array}{l}\text { Upaya pencegahan filariasis (kaki gajah) dapat dilakukan dengan melindungi } \\
\text { diri dari gigitan nyamuk, seperti memasang kawat kasa. }\end{array}$ & 78 & 73,6 & 28 & 26,4 \\
\hline 7 & $\begin{array}{l}\text { Jika saudara sudah meminum obat POMP filariasis tahun lalu, maka tahun ini } \\
\text { tidak perlu meminum obat tersebut lagi. }\end{array}$ & 17 & 16,0 & 89 & 84,0 \\
\hline 8 & $\begin{array}{l}\text { Setelah meminum obat yang diberikan oleh petugas pengobatan massal dan } \\
\text { timbul efek samping, maka menurut saudara tidak perlu untuk meminum } \\
\text { obat POMP filariasis lagi. }\end{array}$ & 44 & 41,5 & 62 & 58,5 \\
\hline 9 & $\begin{array}{l}\text { Meskipun memiliki rasa takut terhadap timbulnya efek samping obat filariasis, } \\
\text { namun keteraturan meminum obat harus tetap dilakukan. }\end{array}$ & 86 & 81,1 & 20 & 18,9 \\
\hline 10 & Tidak perlu menjauhi penderita filariasis. & 83 & 78,3 & 23 & 21,7 \\
\hline
\end{tabular}

Berdasarkan Tabel 2, diketahui bahwa pernyataan yang paling banyak direspon setuju oleh responden adalah penyataan mengenai tindakan untuk langsung berobat ke puskesmas atau dokter jika menderita penyakit filariasis (100\%). Sedangkan, pernyataan yang paling banyak mendapat respon tidak setuju adalah mengenai sikap responden utuk tidak minum obat pencegahan filariasis lagi tahun ini jika tahun lalu sudah pernah minum (84\%). Berikut gambaran variabel pengetahuan dan sikap tentang pencegahan filariasis di Kecamatan Cilimus.

Tabel 3. Distribusi Frekuensi Tingkat Pengetahuan dan Sikap tentang Pencegahan Filariasis di Kecamatan Cilimus

\begin{tabular}{llll}
\hline No. & \multicolumn{1}{c}{ Variabel } & F & $\%$ \\
\hline 1. & Tingkat pengetahuan & & \\
& Kurang & 21 & 19,8 \\
& Cukup & 32 & 30,2 \\
& Baik & 53 & 50,5 \\
\hline 2. & Sikap & & \\
& Negatif & 53 & 50,0 \\
& Positif & 53 & 50,0 \\
\hline
\end{tabular}

Berdasarkan Tabel 3, diketahui bahwa sebagian responden memiliki pengetahuan yang baik mengenai pencegahan filariasis yaitu sebanyak 53 orang (50\%). Untuk variabel sikap, jumlah responden yang memiliki sikap positif dan sikap negatif adalah sama, masing-masing berjumlah 53 orang (50\%). Berikut disajikan pada Tabel 4 gambaran perilaku pencegahan filariasis di Kecamatan Cilimus.

Tabel 4. Gambaran Perilaku Pencegahan Filariasis di Kecamatan Cilimus

\begin{tabular}{clcc}
\hline No. & \multicolumn{1}{c}{ Variabel } & F & $\%$ \\
\hline \multirow{2}{*}{1} & Minum obat pencegahan filariasis & & \\
& Tidak Minum & 19 & 17,9 \\
& Minum & 87 & 82,1 \\
\hline
\end{tabular}




\begin{tabular}{llcc}
\hline 2 & Menggunakan obat nyamuk & & \\
& Tidak & 40 & 37,7 \\
& Ya & 66 & 62,3 \\
\hline 3 & Menggunakan kelambu & & \\
& Tidak & 101 & 95,3 \\
& Ya & 5 & 4,7 \\
\hline 4 & Menggunakan kawat kasa & & \\
& Tidak & 54 & 50,9 \\
& Ya & 52 & 49,1 \\
\hline 5 & Kebiasaan menggantung pakaian & & \\
& Ya & 56 & 52,8 \\
& Tidak & 50 & 47,2 \\
\hline
\end{tabular}

Berdasarkan Tabel 4, diketahui bahwa sebagian besar responden minum obat pencegahan filariasis yang dibagikan setiap bulan Oktober dengan jumlah responden sebanyak 87 orang $(82,1 \%)$. Lebih dari sebagian responden memiliki kebiasaan menggunakan obat nyamuk sebagai bentuk upaya untuk mencegah terjadinya kontak dengan nyamuk, dengan jumlah responden sebanyak 66 orang $(62,3 \%)$. Sebagian besar responden tidak menggunakan kelambu saat mereka tidur dengan jumlah responden sebanyak 101 orang (95,3\%). Lebih dari sebagian responden tidak menggunakan kawat kasa pada ventilasi rumahnya dengan jumlah 54 orang $(50,9 \%)$. Untuk variabel kebiasaan menggantung pakaian, lebih dari sebagian responden terbiasa menggantung pakaian di rumahnya dengan jumlah 56 orang (52,8\%). Sebagian besar responden terbiasa menutup tempat penampungan air di rumahnya dengan jumlah responden sebanyak 93 orang $(87,7 \%)$. Untuk variabel mengelola barang bekas, proporsi responden terbanyak adalah mereka yang memiliki kebiasaan mengubur barang bekas yaitu sebanyak 64 orang $(60,4 \%)$.

Tabel 5. Distribusi Frekuensi Kategori Perilaku Pencegahan Filariasis di Kecamatan Cilimus

\begin{tabular}{|c|c|c|}
\hline Perilaku Pencegahan Filarisis & $\mathrm{F}$ & $\%$ \\
\hline Kurang baik & 50 & 47,2 \\
\hline Baik & 56 & 52,8 \\
\hline Total & 106 & 100 \\
\hline
\end{tabular}

Tabel 5 menunjukkan bahwa proporsi responden lebih banyak yang memiliki perilaku pencegahan yang baik dengan jumlah responden 56 orang (52,8\%). Variabel perilaku pencegahan filariasis dibagi menjadi dua kategori, yaitu kurang baik dan baik, untuk memudahkan proses analisis bivariat.

Tabel 6. Analisis Bivariat antara Variabel Pengetahuan dan Sikap dengan Perilaku Pencegahan Filariasis di Kecamatan Cilimus

\begin{tabular}{|c|c|c|c|c|c|c|c|c|}
\hline \multirow{3}{*}{ Variabel } & \multicolumn{6}{|c|}{ Perilaku Pencegahan Filarisis } & \multirow{3}{*}{ p-value } & \multirow{3}{*}{ OR $(95 \% \mathrm{CI})$} \\
\hline & \multicolumn{2}{|c|}{ Kurang baik } & \multicolumn{2}{|c|}{ Baik } & \multicolumn{2}{|c|}{ Total } & & \\
\hline & $\mathrm{F}$ & $\%$ & $\mathrm{~F}$ & $\%$ & $\mathrm{~F}$ & $\%$ & & \\
\hline \multicolumn{9}{|l|}{ Pengetahuan } \\
\hline Kurang & 17 & 81,0 & 4 & 19,0 & 21 & 100 & 0,001 & \multirow{2}{*}{$\begin{array}{c}6,697 \\
(95 \% \text { CI }: 2,072-21,649)\end{array}$} \\
\hline Cukup-baik & 33 & 38,8 & 52 & 61,2 & 86 & 100 & & \\
\hline \multicolumn{9}{|l|}{ Sikap } \\
\hline Negatif & 34 & 64,2 & 19 & 35,8 & 53 & 100 & 0,0001 & \multirow{2}{*}{$\begin{array}{c}4,138 \\
(95 \% \text { CI }: 1,838-9,319)\end{array}$} \\
\hline Positif & 16 & 30,2 & 37 & 69,8 & 53 & 100 & & \\
\hline
\end{tabular}

Tabel 6 menunjukkan hasil analisis bivariat antara variabel pengetahuan dan sikap dengan perilaku pencegahan filariasis menggunakan uji chi square. Berdasarkan hasil analisis bivariat, diketahui bahwa terdapat hubungan yang signifikan antara pengetahuan dan perilaku pencegahan filariasis dengan nilai $p$ sebesar 0,001. Nilai odd ratio sebesar 6,697 mengindikasikan orang yang memiliki pengetahuan yang kurang 
cenderung 6,697 kali lebih besar menerapkan perilaku pencegahan filariasis yang kurang dibandingkan orang yang memiliki pengetahuan yang cukup baik.

Analisis bivariat antara variabel sikap dan perilaku pencegahan filariasis menunjukkan hasil variabel sikap memiliki korelasi yang signifikan dengan perilaku pencegahan filariasis ( $p=0,0001$ ). Nilai odd ratio sebesar 4,138 mengindikasikan orang yang memiliki sikap negatif cenderung 4,138 kali lebih besar menerapkan perilaku pencegahan filariasis yang kurang baik dibandingkan dengan orang yang memiliki sikap positif.

\section{PEMBAHASAN}

\section{Gambaran Perilaku Pencegahan Filariasis}

Hasil penelitian menunjukkan mayoritas responden memiliki perilaku yang baik terkait pencegahan penyakit filariasis. Terdapat beberapa perilaku yang dapat dilakukan masyarakat untuk mencegah infeksi filariasis, yang pertama adalah minum obat pencegahan filariasis.

Sebagian besar responden $(82,1 \%)$ di Kecamatan Cilimus sudah minum obat pencegahan filariasis setiap bulan Oktober. Cakupan kepatuhan minum obat dari hasil penelitian ini lebih tinggi jika dibandingkan dengan cakupan minum obat dari hasil penelitian Amelia dengan persentase hanya 61,8\%. ${ }^{12}$

Program Pemberian Obat Pencegahan Massal Filariasis merupakan program yang dicanangkan oleh pemerintah pada kabupaten/kota endemis filariasis. Pengobatan massal ini dilakukan setahun sekali pada bulan Oktober selama lima tahun berturutturut. Obat yang diberikan bertujuan untuk mematikan mikrofilaria secara serentak bagi seluruh penduduk di daerah tersebut. ${ }^{2}$ Dengan adanya program yang telah dikoordinasikan oleh Global Program to Eliminate Lymphatic Filariasis (GPELF) ini, prevalensi infeksi dan morbiditas filariasis telah menurun di seluruh dunia. ${ }^{20} \mathrm{Hal}$ ini dikarenakan kepadatan parasit yang beredar dalam darah orang yang terinfeksi dapat dikurangi dan prevalensi infeksi di masyarakat dapat dikendalikan pada tingkat yang rendah sehingga tidak terjadi lagi penularan oleh vektor nyamuk. ${ }^{21}$

Untuk mencapai penghentian penularan parasit, program POPM harus mencapai cakupan program minimal $80 \%$ selama 5-6 tahun pengobatan tahunan atau lebih lama di daerah dengan microfilaria rate yang tinggi. ${ }^{21}$ Dari hasil penelitian disimpulkan masyarakat Kecamatan Cilimus sudah patuh untuk minum obat pencegahan filariasis, dengan persentase cakupan minum obat $>80 \%$.

Perilaku kedua adalah menggunakan obat nyamuk. Kebiasaan menggunakan obat nyamuk telah dilakukan oleh lebih dari sebagian responden (62,3\%). Hasil penelitian ini sejalan dengan penelitian yang dilakukan di Kabupaten Aceh Utara dan Kabupaten Barito Kuala, persentase responden yang sudah terbiasa menggunakan obat nyamuk untuk melindungi diri dari kontak dengan nyamuk masing-masing sebesar 50,75\% dan 64,44\%. ${ }^{16,22}$ Penelitian Sofia dan Nadira membuktikan kebiasaan menggunakan obat nyamuk berhubungan secara signifikan dengan kejadian filariasis. Perilaku menggunakan obat nyamuk dilakukan untuk menghindari gigitan vektor penular filariasis. Perilaku penggunaan obat nyamuk pada malam hari dan penggunaan kelambu ketika tidur diharapkan dapat memberikan perlindungan kepada masyarakat dari proses penularan filariasis dan malaria. ${ }^{23}$

Perilaku ketiga adalah kebiasaan menggunakan kelambu. Mayoritas responden dalam penelitian ini tidak menggunakan kelambu. Penelitian di Kabupaten Mamuju Utara menunjukkan hasil serupa dimana lebih banyak responden yang tidak menggunakan kelambu saat mereka tidur. ${ }^{10}$ Hasil ini berbeda dengan penelitian di Kabupaten Bintan, yang menunjukkan lebih dari sebagian responden di Kabupaten 
Bintan sudah terbiasa menggunakan kelambu saat mereka tidur $(68,4 \%)$. Bahkan dalam penelitiannya, telah dikonfirmasi bahwa kebiasaan menggunakan kelambu memiliki hubungan yang signifikan dengan kejadian filariasis. ${ }^{18}$ Penelitian di Provinsi Sumatera Barat juga menunjukkan bahwa kebiasaan tidak menggunakan kelambu menjadi faktor risiko terjadinya filariasis. ${ }^{24}$

Efektivitas penggunaan kelambu dalam menurunkan risiko terjadinya filariasis telah dibuktikan di Papua Nugini. Hasil penelitian ini menunjukkan angka gigitan khusus nyamuk Anopheles di desa berkisar antara 6,4 hingga 61,3 gigitan per orang per hari. Kemudian angka tersebut mengalami penurunan menjadi 1,1 hingga 9,4 gigitan setelah dilakukan pendistribusian kelambu pada masyarakat di sana selama 11 bulan $(p<0,001)$. Pada periode yang sama, laju deteksi Wuchereria. bancrofti pada nyamuk Anopheles menurun dari 1,8\% menjadi 0,4\% $(p=0,005)$, dan laju deteksi DNA filaria menurun dari 19,4\% menjadi 14,9\% $(p=0,13)$. Bahkan penelitian ini juga telah membuktikan terjadinya peningkatan dalam hal probabilitas penghentian penularan filariasis yang awalnya hanya $<1,0 \%$ menjadi 4,9-95\% setelah kelambu didistribusikan selama 11 bulan pada lima desa yang memiliki prevalensi mikrofalia $2-38 \% .{ }^{25}$

Perilaku keempat adalah perilaku menggunakan kawat kasa yang sudah dilakukan oleh sebagian responden dalam penelitian ini. Hasil penelitian ini menunjukkan persentase responden yang sudah memasang kawat kasa lebih tinggi dibandingkan dengan penelitian yang dilakukan Ikhwan, dengan persentasenya hanya 20,4\%. Pemasangan kawat kasa umumnya dilakukan pada ventilasi udara yang biasanya menjadi tempat masuknya nyamuk ke dalam rumah. Berdasarkan penelitian yang dilakukan di Kuningan ${ }^{17}$ serta di Kabupaten Barito Kuala, keberadaan kawat kasa pada ventilasi rumah memiliki hubungan signifikan dengan kejadian filariasis. ${ }^{16}$ Orang yang di rumahnya tidak terpasang kawat kasa lebih berisiko terinfeksi filariasis karena akan mempermudah nyamuk untuk dapat masuk ke dalam rumah. Faktor ekonomi responden yang kurang menjadi penyebab mengapa mereka tidak memasang kawat kasa. ${ }^{16}$

Perilaku selanjutnya adalah perilaku menggantung pakaian yang masih dilakukan oleh sebagian responden dalam penelitian ini. Hasil penelitian yang dilakukan oleh Sularno bahkan memperlihatkan sebagian besar responden di Kecamatan Buaran, Kabupaten Pekalongan memiliki kebiasaan menggantung pakaian. ${ }^{15}$ Hasil observasi lingkungan yang dilakukan Yanuarini di Kabupaten Pekalongan menunjukkan, ditemukan banyak gantungan baju dan barang-barang bekas yang dapat menampung air hujan di sekitar rumah pada 70,4\% rumah responden kelompok kasus. ${ }^{13}$

Perilaku menggantung pakaian merupakan perilaku yang seharusnya dihindari dalam upaya pencegahan filariasis karena pakaian yang dibiarkan menggantung dapat menjadi tempat peristirahatan nyamuk atau resting place. Keberadaan resting place tersebut dapat meningkatkan risiko penularan filariasis. Hasil penelitian lain membuktikan bahwa responden yang di rumahnya terdapat resting places berisiko 6,087 kali lebih besar terjangkit filariasis dibandingkan dengan responden yang di rumahnya tidak terdapat resting places. Adapun jenis nyamuk yang ditemukan pada resting place di dinding rumah, pakaian bergantung, perabot rumah, semak-semak bervariasi dalam penelitian tersebut, yaitu Anopheles letifer, Mansonia uniformis, Culex tritaeniorhyncus, Culex vishnui, Culex cressipes, dan Mansonia annulifera. ${ }^{26}$

Penelitian lain dikembangkan oleh Supriyono di Desa Gulinggang Kabupaten Balangan Provinsi Kalimantan Selatan dengan melakukan penangkapan nyamuk di dalam dan di luar rumah responden dari pukul 18:00-06:00. Penelitian tersebut berhasil menemukan lima spesies nyamuk, yaitu Mansonia uniformis, Ma. dives, Ma. annulifera, Ma. annulata, dan Ma. bonneae. Diantara kelima spesies nyamuk tersebut, spesies nyamuk yang paling banyak tertangkap di dalam rumah yaitu Ma. uniformis (37.99\%), dengan 
puncak kepadatan nyamuk tersebut mengisap darah orang di dalam rumah terjadi pada pukul 18:00-18:45. ${ }^{27}$ Berdasarkan hasil penelitian tersebut dapat disimpulkan bahwa penularan filariasis dapat terjadi di dalam rumah, karena ditemukannya vektor filariasis. Oleh karena itu, kebiasaan menggantung pakaian sebaiknya dihindari untuk mencegah penularan filariasis.

Penelitian yang dilakukan di Kabupaten Pekalongan menunjukkan terdapat hubungan yang signfikan antara keberadaan breeding places dengan kejadian filariasis. ${ }^{13}$ Nyamuk merupakan serangga yang melangsungkan siklus kehidupannya dalam air, sehingga jika tidak terdapat air maka siklus hidup nyamuk akan terputus. ${ }^{28}$ Oleh karena itu, hal yang dapat kita lakukan untuk mencegah perkembangbiakan nyamuk adalah tidak membiarkan adanya genangan air di sekitar rumah.

Filariasis dapat disebarkan oleh nyamuk Mansonia, Anopheles, Culex, dan Armigeres. ${ }^{29,28}$ Di setiap daerah, vektor yang dapat menularkan filariasis akan berbeda tergantung pada kondisi lingkungan wilayah setempat. Setiap vektor nyamuk memiliki tempat perindukan dan perkembangbiakan yang berbeda-beda. Hasil penelitian yang dilakukan di Kabupaten Sumba Barat Daya sebagai daerah endemis filaraisis menemukan spesies An. vagus, An. barbirostris, An. annularis, Cx. vishnui, $C x$. bitaeniorhynchus, Cx. quinquefasciatus, dan Ar. Kuchingensis. ${ }^{29}$

Studi observasional yang dilakukan di Kabupaten Bandung dengan melakukan penangkapan nyamuk dewasa melalui koleksi pendaratan dan peristirahatan manusia di dalam-luar ruangan, telah berhasil mengidentifikasi enam spesies vektor nyamuk filariasis. Vektor primer filariasis, Culex quinquefasciatus dan Cx. tritaeniorhynchus ditemukan sebagai spesies dominan dengan waktu pendaratan puncak antara jam 9 malam - 1 dini hari. Menurut Kementerian Kesehatan, $C x$. quinquefasciatus adalah vektor utama filariasis di Indonesia dan telah terdokumentasi dibanyak wilayah di Indonesia antara lain Aceh, Jawa Barat, Jakarta, Jawa Tengah, dan Papua. ${ }^{30}$

Genangan air merupakan tempat perindukan yang paling disenangi oleh nyamuk $C x$. quinquefasciatus, terutama genangan air yang tercemar oleh limbah rumah tangga. ${ }^{31}$ Salah satu cara yang dapat dilakukan dalam menerapkan metode pengelolaan lingkungan adalah melakukan upaya pemberantasan sarang nyamuk melalui kegiatan membersihkan tanaman air, menimbun genangan air, membersihkan selokan, dan mengalirkan air yang menggenang. ${ }^{13}$ Kegiatan membersihan lingkungan dari genangan air dan tumbuhan yang hidup di air, secara tidak langsung memberikan implikasi dalam mengurangi keragaman spesies nyamuk dan memutus rantai transmisi filariasis. ${ }^{27}$

\section{Hubungan Pengetahuan tentang Pencegahan Filariasis dengan Perilaku Pencegahan Filariasis}

Hasil penelitian menunjukkan baru sebagian responden yang memiliki pengetahuan yang baik mengenai pencegahan filariasis. Hasil analisis bivariat diketahui bahwa adanya hubungan signifikan antara variabel pengetahuan tentang pencegahan filariasis dengan perilaku pencegahan filariasis. Hal ini sejalan dengan penelitian yang dilakukan di Kabupaten Pekalongan, ${ }^{32}$ Kabupaten Demak, ${ }^{33}$ dan di Desa Kasang Lopak Alai Kecamatan Kumpeh Ulu Kabupaten Muaro Jambi. ${ }^{34}$

Perilaku tidak selalu mengikuti urutan tertentu sehingga terbentuknya perilaku positif tidak selalu dipengaruhi oleh pengetahuan dan sikap positif. Namun, secara minimal jika didasari pengetahuan yang cukup, perilaku positif yang terbentuk relatif lebih lama. Hal ini menunjukkan perilaku dengan kekhasan dan keunikannya dipengaruhi oleh banyak variabel atau faktor. ${ }^{35}$ Menurut Lawrence Green (1980) dalam Notoatmodjo, perilaku dipengaruhi oleh tiga faktor utama, yang dirangkum dalam akronim PRECEDE: Predisposing, Enabling, and Reinforcing Causes in Educational Diagnosis and Evaluation. Ketiga faktor tersebut yaitu: 1) faktor-faktor predisposisi, termanifestasi 
dalam pengetahuan, sikap, kepercayaan, keyakinan, nilai-nilai, dan sebagainya; 2) faktor-faktor pemungkin, termanifestasi dalam lingkungan fisik, tersedia atau tidak tersedianya fasilitas atau sarana kesehatan, misalnya puskesmas, obat-obatan, alat-alat kontrasepsi, jamban, dan sebagainya; dan 3) faktor-faktor pendorong atau penguat, termanifestasi dalam sikap dan perilaku petugas kesehatan atau petugas lain, yang merupakan kelompok referensi dari perilaku masyarakat. ${ }^{36}$

Dengan melihat model yang dikemukakan oleh Lawrence Green, maka pengetahuan yang diteliti termasuk ke dalam faktor predisposisi yang dapat memengaruhi perilaku seseorang. Akan tetapi, kita juga dapat mengetahui bahwa pengetahuan bukanlah satusatunya faktor yang dapat memengaruhi perilaku. Ada faktor lain seperti kepercayaan, nilai, keyakinan dan sebagainya yang dapat memengaruhi, namun tidak diteliti dalam penelitian ini sehingga hal ini menjadi keterbatasan dalam penelitian ini.

Ada berbagai cara yang dapat dilakukan untuk memeroleh pengetahuan masyarakat mengenai filariasis yaitu mengakses berbagai sumber pengetahuan dari berbagai media seperti poster maupun media cetak ataupun mendapatkan informasi secara langsung dari penyuluh kesehatan atau kader kesehatan ${ }^{32}$. Maka dari itu, dalam upaya pencegahan filariasis, sangat penting bagi tenaga kesehatan untuk selalu memberikan penyuluhan atau memberikan informasi kepada masyarakat agar masyarakat semakin paham dan bertambah pengetahuannya mengenai filariasis dan upaya pencegahannya. ${ }^{32}$

Peran dari stakeholder seperti instansi kesehatan juga penting untuk dapat meningkatkan pengetahuan masyarakat mengenai pencegahan filariasis, misalnya dengan melakukan promosi kesehatan mengenai filariasis dan upaya pencegahannya. Selain itu, adanya dukungan dari tokoh masyarakat dalam program pengendalian filariasis yang dicanangkan oleh pemerintah, akan semakin meningkatkan animo masyarakat untuk berpartisipasi dalam program tersebut. Selain tokoh masyarakat, keterlibatan kader juga memiliki peran yang penting untuk memobilisasi masyarakat dalam gerakan pengendalian dan pencegahan filariasis.

Dukungan tokoh masyarakat dan kader menjadi faktor pendorong/penguat (reinforcing factors), karena mereka merupakan kelompok referensi dari masyarakat. ${ }^{9}$ Hasil penelitian lain menunjukkan pengetahuan tokoh masyarakat mengenai gejala filariasis kurang baik, namun pengetahuan mengenai akibat dari filariasis cukup baik. Mereka juga setuju dengan dilaksanakannya kegiatan POPM filariasis. Tokoh masyarakat memiliki beberapa peranan apabila dilibatkan dalam program pemerintah yaitu sebagai mobilisator, katalisator, motivator, dan diseminator. ${ }^{37}$

\section{Hubungan Sikap tentang Pencegahan Filariasis dengan Perilaku Pencegahan Fiariasis}

Hasil analisis bivariat diketahui bahwa adanya hubungan signifikan antara variabel sikap tentang perilaku pencegahan filariasis dengan perilaku filariasis. Hal ini sejalan dengan penelitian yang dilakukan di Kabupaten Pekalongan ${ }^{32}$, Kabupaten Demak ${ }^{33}$, dan di Desa Kasang Lopak Alai Kecamatan Kumpeh Ulu Kabupaten Muaro Jambi. ${ }^{34}$

Sikap merupakan sebuah reaksi dari seseorang setelah terpapar stimulus dari luar. Umumnya sikap masih bersifat tertutup sehingga belum berubah menjadi perilaku. Terbentuknya sikap berawal dari terpaparnya informasi yang kemudian membentuk pengetahuan masyarakat. Setelah pengetahuan terbentuk, orang tersebut akan memberikan reaksi awal yang disebut sikap. Sikap yang ditunjukkan oleh masyarakat dapat memengaruhi perilaku yang akan dilakukan. Namun, tidak semua sikap dapat langsung berubah menjadi perilaku. Ada beberapa faktor yang memengaruhinya seperti budaya, pengalaman pribadi, atau pengaruh dari orang-orang sekitar seperti keluarga atau tokoh masyarakat. ${ }^{38}$ Kedalaman pengetahuan itu sendiri dapat diukur 
dengan disesuaikan pada enam tingkatan, yaitu tahu, memahami, aplikasi, analisis, sintesis dan evaluasi. Kemudian diikuti tiga tingkatan sikap yaitu menerima, merespon, menghargai dan bertanggung jawab.

Teori Breckler dan Wiggins dalam Azwar menyatakan perolehan sikap melalui pengalaman akan berpengaruh langsung terhadap perilaku berikutnya. Pengaruh langsung tersebut lebih berupa predisposisi perilaku yang akan direalisasikan hanya dalam kondisi dan situasi memungkinkan. Semakin kompleks situasinya dan semakin banyak faktor yang ikut menjadi pertimbangan dalam bertindak, maka semakin sulit memprediksikan perilaku dan semakin sulit pula menafsirkannya sebagai indikator sikap seseorang. Hal inilah yang dijelaskan oleh Ajzen dan Fishbein pada 1980 dalam Azwar, yang mengajukan model theory of reasoned action yaitu respons perilaku ditentukan tidak saja oleh sikap individu, akan tetapi juga oleh norma subjektif yang ada dalam diri individu yang bersangkutan. Hal ini didukung pula oleh model teori Kurt Lewin yang menyatakan bahwa perilaku merupakan fungsi dari faktor kepribadian individual dan faktor lingkungan. ${ }^{39}$

\section{KESIMPULAN}

Penelitian ini menyimpulkan bahwa pengetahuan dan sikap memiliki hubungan yang signfikan dengan perilaku pencegahan filariasis. Oleh karena itu, diperlukan upaya peningkatan pengetahuan mengenai pencegahan filariasis dengan memaksimalkan media promosi kesehatan (audio visual, leaflet, pamflet, brosur, web, dan lainlain) sehingga masyarakat memiliki sikap positif dan mampu menerapkan perilaku pencegahan yang baik. Terutama pada perilaku yang masih kurang dilakukan oleh masyarakat, seperti perilaku menggunakan kelambu, memasang kawat kasa, dan tidak menggantung benda-benda, termasuk pakaian di dalam rumah yang dapat menjadi tempat bersitirahat nyamuk. Upaya ini juga dapat dilakukan dengan bekerjasama atau melibatkan berbagai stakeholder seperti perguruan tinggi dan pimpinan wilayah setempat.

\section{UCAPAN TERIMA KASIH}

Penulis mengucapkan terima kasih kepada Dinas Kesehatan Kabupaten Kuningan dan Puskesmas Cilimus yang telah memberikan izin serta membantu proses penelitian ini. Selain itu juga ucapan terima kasih ditujukan kepada seluruh staf Universitas Siliwangi yang telah memberikan dukungan dalam melakukan penelitian ini.

\section{KONTRIBUSI PENULIS}

Peran penulis pada artikel ini yaitu Nissa Noor Annashr sebagai kontributor utama dan Fathi Muhamad Rahmadi sebagai kontributor anggota. Kontribusi setiap penulis dapat dilihat pada rincian berikut:

Konsep; Mengumpulkan Data; Mengolah Data;

: NNA

Analisis Data; Sponsor Pendanaan; Investigasi;

Metodologi; Manajemen Proyek; Validasi

Sumber Daya

Visualisasi; Menulis, Mengkaji, dan Mengedit

: FMR

: NNA, FMR

\section{DAFTAR RUJUKAN}

1. Meliyanie G, Andiarsa D. Program eliminasi lymphatic filariasis di Indonesia. J Heal Epidemiol Commun Dis. 2017;3(2):63-70.

2. Kemenkes RI. Situasi filariasis di Indonesia. Infodatin Pusat Data dan Informasi Kementerian Kesehatan RI. Kemenetrian Kesehatan RI; 2019. p. 1-12. 
3. Offei M, Anto F. Compliance to mass drug administration programme for lymphatic filariasis elimination by community members and volunteers in the Ahanta West District of Ghana. J Bacteriol Parasitol. 2014;05(01):1-6.

4. World Health Organization. Morbidity management and disability prevention in lymphatic filariasis [Internet]. WHO; 2013. 1-44 p.

5. Ojha CR, Joshi B, Khagendra Prakash KC, Dumre SP, Yogi KK, Bhatta B, et al. Impact of mass drug administration for elimination of lymphatic filariasis in Nepal. PLoS Negl Trop Dis. 2017;11(7):1-12.

6. Upadhyayula SM, Mutheneni SR, Kadiri MR, Kumaraswamy S, Nagalla B. A cohort study of lymphatic filariasis on socio economic conditions in Andhra Pradesh , India. PLOS ONE J [Internet]. 2012;7(3):1-8. Available from: https://journals.plos. org/plosone/article?id=10.1371/journal.pone.0033779

7. Badan Penelitian dan Pengambangan Kesehatan Kementerian Kesehatan RI. Laporan nasional Riskesdas 2018 [Internet]. Jakarta: Badan Penelitian dan Pengembangan Kesehatan; 2019. Available from: http://labdata.litbang.kemkes. go.id/images/download/laporan/RKD/2018/Laporan_Nasional_RKD2018_FINAL. pdf

8. Badan Penelitian dan Pengembangan Kesehatan Kementerian Kesehatan RI. Laporan provinsi Jawa Barat, Riskesdas 2018. Lembaga Penerbit Badan Penelitian dan Pengembangan Kesehatan. Jakarta: Badan Penelitian dan Pengembangan Kesehatan RI; 2019. 140-151 p.

9. Amalia IS, Annashr NN. Faktor sosiodemografi dan perilaku yang berhubungan dengan kejadian filariasis di Kabupaten Kuningan. J Kampus STIKes YPIB Majalengka [Internet]. 2018;6(13):1-19. Available from: http://e-journal.stikesypib. ac.id/index.php/JK/article/view/3/6

10. Veridiana NN, Chadijah S, Ningsi N. Pengetahuan, sikap dan perilaku masyarakat terhadap filariasis di Kabupaten Mamuju Utara, Sulawesi Barat. Bul Penelit Kesehat [Internet]. 2015;43(1):47-54. Available from: http://ejournal.litbang.kemkes.go.id/ index.php/BPK/article/viewFile/3968/3798

11. Astuti AB, Mulyanti S. Analisis faktor resiko filariasis di wilayah kerja Puskesmas Ngemplak Kabupaten Boyolali Jawa Tengah. J Terpadu Ilmu Kesehat. 2019;8(1):7586.

12. Amelia R. Analisis faktor risiko kejadian penyakit filariasis. Unnes J Public Heal. 2014;3(1):1-12.

13. Yanuarini C. Faktor-faktor yang berhubungan dengan kejadian filariasis di Puskesmas Tirto I Kabupaten Pekalongan. Fikkes J Keperawatan. 2015;8(1):73-86.

14. Afra D, Harminarti N, Abdiana. Faktor-faktor yang berhubungan dengan kejadian filariasis di Kabupaten Padang Pariaman Tahun 2010-2013. J Kesehat Andalas. 2016;5(1):111-9.

15. Sularno S, Nurjazuli, Raharjo M. Faktor-faktor yang berhubungan dengan kejadian filariasis Di Kecamatan Buaran Kabupaten Pekalongan. J Kesehat Lingkung Indones. 2017;16(1):22-8.

16. Rahmat A, Rahmayanti D, Rachmawati K. Faktor-faktor yang berhubungan dengan kejadian filariasis di Kabupaten Barito Kuala. Dunia Keperawatan J Keperawatan dan Kesehatab [Internet]. 2020;8(1):48-58. Available from: https://ppjp.ulm.ac.id/ journal/index.php/JDK/article/view/6919

17. Annashr NN, Amalia IS. kondisi lingkungan dan kejadian filariasis di Kabupaten Kuningan. Wind Heal J Kesehat [Internet]. 2021;04(01):85-97. Available from: http:// jurnal.fkmumi.ac.id/index.php/woh/article/view/269

18. Ikhwan Z, Herawati L, Suharti. Environmental, Behavioral factors and filariasis incidence in Bintan District, Riau Islands Province. Kesmas Natl Public Heal Journal. 2016;11(3):39-45. 
19. da-Costa Vroom FB, Aryeetey R, Boateng R, Anto F, Aikins M, Gyapong M, et al. Data reporting constraints for the lymphatic filariasis mass drug administration activities in two districts in Ghana: A qualitative study. SAGE Open Med. 2015;3:205031211559408.

20. Erickson SM, Thomsen EK, Keven JB, Vincent N, Koimbu G, Siba PM, et al. Mosquitoparasite interactions can shape filariasis transmission dynamics and impact elimination programs. PLoS Negl Trop Dis [Internet]. 2013;7(9):1-7. Available from: https://journals.plos.org/plosntds/article?id=10.1371/journal.pntd.0002433

21. Gyapong JO, Owusu IO, da-Costa Vroom FB, Mensah EO, Gyapong M. Elimination of lymphatic filariasis: current perspectives on mass drug administration. Res Rep Trop Med [Internet]. 2018;Volume 9:25-33. Available from: https://www.ncbi.nlm. nih.gov/pmc/articles/PMC6047620/

22. Sofia R, Nadira CS. Analisis risiko penularan filariasis limfatik di Kabupaten Aceh Utara. AVERROUS J Kedokt dan Kesehat Malikussaleh. 2020;6(1):1-16.

23. Yunarko R, Patanduk Y. Distribusi filariasis Brugia Timori dan Wuchereria Bancrofti di Desa Kahale, Kecamatan Kodi Balaghar, Kabupaten Sumba Barat Daya, Nusa Tenggara Timur. Balaba J Litbang Pengendali Penyakit Bersumber Binatang Banjarnegara. 2016;12(2):89-98.

24. Mangguang M, Kusnanto H, Lazuardi L. Risk factors filariasis incident by geographic information systems approach in. Int J Recent Adv Multidiscip Res. 2015;02(06):0463-70.

25. Reimer LJ, Thomsen EK, Tisch DJ, Henry-Halldin CN, Zimmerman PA, Baea ME, et al. Insecticidal bed nets and filariasis transmission in Papua New Guinea. N Engl J Med [Internet]. 2013;369(8):745-53. Available from: https://www.ncbi.nlm.nih. gov/pmc/articles/PMC3835352/pdf/nihms526411.pdf

26. Purnama W, Nurjazuli, Raharjo M. Faktor lingkungan dan perilaku masyarakat yang berhubungan dengan kejadian filariasis di Kecamatan Muara Pawan Kabupaten Ketapang Provinsi Kalimantan Barat. J Kesehat Lingkung Indones [Internet]. 2017;16(1):8-16. Available from: https://ejournal.undip.ac.id/index.php/ jkli/article/view/11526

27. Supriyono S, Tan S, Hadi UK. Perilaku nyamuk mansonia dan potensi reservoar dalam penularan filariasis di Desa Gulinggang Kabupaten Balangan Provinsi Kalimantan Selatan. ASPIRATOR - J Vector-borne Dis Stud [Internet]. 2017;9(1):110. Available from: http://ejournal.litbang.kemkes.go.id/index.php/aspirator/ article/view/4443/4946\%0A\%0A\%0A\%0A

28. Mutiara H, Anindita. Filariasis: pencegahan terkait faktor risiko. Majority. 2016;5(2):1-6.

29. Tallan MM, Mau F. Karakteristik habitat perkembangbiakan vektor filariasis di Kecamatan Kodi Balaghar Kabupaten Sumba Barat Daya. ASPIRATOR - J Vectorborne Dis Stud [Internet]. 2016;8(2):55-62. Available from: http://ejournal.litbang. kemkes.go.id/index.php/aspirator/article/view/4243/4572

30. Astuti EP, Ipa M, Wahono T, Ruliansyah A, Hakim L, Dhewantara PW. The distribution of Culex spp (Diptera: Culicidae) in selected endemic lymphatic filariasis villages in Bandung District West Java Indonesia. ASPIRATOR - J Vectorborne Dis Stud [Internet]. 2017;9(2):61-8. Available from: http://ejournal.litbang. kemkes.go.id/index.php/aspirator/article/view/6299/5444

31. Sularno S. Faktor-faktor yang berhubungan dengan kejadian filariasis di Kecamatan Buaran Kabupaten Pekalongan. J Kesehat Lingkung Indones. 2017;16(1):22.

32. Agustiantiningsih D. Praktik pencegahan filariasis. KEMAS J Kesehat Masy [Internet]. 2013;8(2):190-7. Available from: https://journal.unnes.ac.id/nju/index. php/kemas/article/view/2821/2877

33. Iswanto F, Rianti E, Musthofa SB. Faktor-faktor yang berhubungan dengan perilaku pencegahaan penyakit filariasis pada masyarakat di Kecamatan Bonang 
Kabupaten Demak. J Kesehat Masy [Internet]. 2017;5(5):990-9. Available from: https://ejournal3.undip.ac.id/index.php/jkm/article/view/19227/18254

34. Monalisa. Hubungan pengetahuan dan sikap keluarga dengan perilaku pencegahan filariasis di Desa Kasang Lopak Alai Kecamatan Kumpeh Ulu Kabupaten Muaro Jambi. J Heal Sport [Internet]. 2013;7(1):1-7. Available from: http://ejurnal.ung. ac.id/index.php/JHS/article/view/1088/885

35. Maulana HDJ. Promosi Kesehatan. Jakarta: Penerbit Buku Kedokteran EGC; 2009.

36. Notoatmodjo S. Ilmu perilaku kesehatan. Jakarta: Rineka Cipta; 2014. 75-76 p.

37. Sitorus H, Ambarita LP, Arisanti M, Manalu HS. Pengetahuan tokoh masyarakat dan kader kesehatan tentang program eliminasi filariasis limfatik di Kecamatan Pemayung Kabupaten Batanghari Provinsi Jambi. ASPIRATOR - J Vector-borne Dis Stud. 2016;8(2):93-100.

38. Hamidi MNS, Asmawati. Hubungan pengetahuan dan sikap kepala keluarga tentang filariasis dengan mengkonsumsi obat pencegahan filariasis di Desa Berancah wilayah UPT Puskesmas Selatbaru tahun 2016. J Ners Univ Pahlawan Tuanku Tambusai [Internet]. 2017;1(2):57-73. Available from: https://journal. universitaspahlawan.ac.id/index.php/ners/article/view/118/87

39. Azwar. Sikap manusia teori dan pengukurannya. Yogyakarta: Pustaka Pelajar; 2015. 